\title{
Article \\ Effects of a Dual-Purpose Inoculant on the Quality and Aerobic Stability of Corn Silage at the Laboratory and Field Scales
}

\author{
Hsiu-Ming Weng ${ }^{1, *} \mathbb{\infty}$, Li-Chen Kao ${ }^{1}$, Shu-Min Wang ${ }^{2}$, Chia-Sheng Chen ${ }^{2}$, Ting-Yu Lee ${ }^{1}$, Hsiao-Tung Chang ${ }^{1} \oplus$, \\ San-Land Young ${ }^{1}$ and Jin-Seng Lin ${ }^{1}$ (D) \\ 1 Culture Collection \& Research Institute, Synbio Tech Inc., Kaohsiung 82151, Taiwan; \\ lckao@synbiotech.com.tw (L.-C.K.); tingyu.lee@synbiotech.com.tw (T.-Y.L.); \\ hsiaotung@synbiotech.com.tw (H.-T.C.); s333@synbiotech.com.tw (S.-L.Y.); jslin@synbiotech.com.tw (J.-S.L.) \\ 2 Hengchun Branch, COA-LRI, Pingtung 94644, Taiwan; smwang@mail.tlri.gov.tw (S.-M.W.); \\ chencsg@mail.tlri.gov.tw (C.-S.C.) \\ * Correspondence: sherry.h.weng@gmail.com
}

Citation: Weng, H.-M.; Kao, L.-C.; Wang, S.-M.; Chen, C.-S.; Lee, T.-Y.; Chang, H.-T.; Young, S.-L.; Lin, J.-S. Effects of a Dual-Purpose Inoculant on the Quality and Aerobic Stability of Corn Silage at the Laboratory and Field Scales. Appl. Sci. 2021, 11, 8257. https://doi.org/10.3390/app11178257

Academic Editor: Monica Gallo

Received: 3 August 2021

Accepted: 2 September 2021

Published: 6 September 2021

Publisher's Note: MDPI stays neutral with regard to jurisdictional claims in published maps and institutional affiliations.

Copyright: (c) 2021 by the authors. Licensee MDPI, Basel, Switzerland. This article is an open access article distributed under the terms and conditions of the Creative Commons Attribution (CC BY) license (https:/ / creativecommons.org/licenses/by/ $4.0 /)$.

\begin{abstract}
This study investigated the effects of a dual-purpose inoculant (DPI) on the fermentation profile, nutritive value, and aerobic stability of silage. The inoculant effect was first examined with minisilos, and the results were later validated with 400-kg silo bales and a 40-t bunker silo. Briefly, whole-plant corn harvested at the one-half to two-thirds milk line stage was chopped and then treated with or without inoculant containing Lactobacillus plantarum LP1028 and Lactobacillus buchneri LBC1029 at application rates of $2.5 \times 10^{5} \mathrm{cfu}$ and $5.0 \times 10^{5} \mathrm{cfu}$ per gram of fresh forage, respectively. The results showed that applying DPI had no effect on the nutritive value in all trials. DPI inoculation also slowed yeast and mold growth in silage under aerobic exposure. Inoculation may double the aerobic stability time after $105 \mathrm{~d}$ of ensiling ( $53.25 \mathrm{vs}$. $113.20 \mathrm{~h}$ ) in a bunker silo. This study successfully examined the effectiveness of DPI in minisilos, and the results were consistent when moving from the laboratory to the field. Applying DPI made the fermentation more heterolactic without compromising the silage nutritive value, and increasing acetic acid acted as antifungal agent to inhibit spoilage microbial growth and improve silage aerobic stability.
\end{abstract}

Keywords: aerobic stability; Lactobacillus plantarum; Lactobacillus buchneri

\section{Introduction}

Seasonal variation in crop production is the main cause of insufficient feed supply in the livestock industry [1]. To address this issue, ensiling has been widely adopted to preserve crops for use when quality feed sources are scarce [2]. As the silo becomes anaerobic, epiphytic lactic acid bacteria (LAB) can ferment water-soluble carbohydrates (WSC) into organic acids, which can lower the silage $\mathrm{pH}$ and therefore inhibit undesirable microbial growth [3]. After silo opening, however, aerobic spoilage may occur as aerobic microorganisms can grow using the fermentation products and carbohydrates of the silage, especially in corn silage [4]. This problem can be severe in silos opened in warm weather or with a slow feed-out rate [5]. Aerobic deterioration not only lowers the palatability and digestibility of silage but also poses a great threat to animal health [6,7].

LAB inoculants have been incorporated into silage-making as an effective practice for decades [8]. Based on the fermentation pathway involved, inoculants can be classified as either homolactic or heterolactic acid bacteria [9]. Homolactic acid bacteria such as Lactobacillus plantarum produce mainly lactic acid, which causes a rapid decrease in $\mathrm{pH}$ [10]. However, lactic acid can be utilized by lactate-assimilating microorganisms upon aerobic exposure [10], making heterolactic acid bacteria such as Lactobacillus buchneri attractive in silage production because they are able to convert lactate to organic acids with strong antifungal characteristics. However, heterolactic fermentation and a longer fermentation period may result in dry matter (DM) loss [11]. Recently, the development of dual-purpose 
inoculants (DPIs) that contain homo- and heterolactic acid bacterial strains has overcome the limitations of using either strain alone $[12,13]$.

Currently, most studies have assessed inoculant efficacy with small-scale silos prepared in the laboratory where the conditions are relatively stable [14-16]. Ferrero et al. [17] indicated that the fluctuating temperature during silo conservation had additive impacts on silage fermentation, which in turn accelerated aerobic deterioration during the feedout phase [17]. Considering the challenging field conditions for proper fermentation, it is essential to validate the results obtained from laboratory-scale trials in farm-scale silos [18]. Silage quality analysis at feed-out would require a plethora of labor inputs and time-consuming laboratory testing. For this reason, many authors have suggested using an infrared thermography camera to measure the silo working face temperature as a simple way to detect the microbial status of silage $[19,20]$. Moreover, the idea of the aerobic stability index (ASI) proposed by Queiroz et al. [21] was also adopted in this study, offering insightful information into heat accumulation in silage over time upon aerobic exposure [21].

The effectiveness of inoculants may be dependent upon their origins. Most inoculants were isolated from fermented foods rather than silage [22-24]. In this case, the inoculants may be less adaptable to the ensiling environment than the inoculants isolated from silage $[24,25]$. The primary outcome of this study aimed to evaluate the efficacy of a DPI containing two silage isolates, Lactobacillus plantarum and Lactobacillus buchneri, on fermentation profile, nutritive value, and aerobic stability with minisilos, and verify the laboratory results on a farm scale for field application. Furthermore, silo face temperature was recorded with an infrared thermography camera to examine silage quality at feed-out under field conditions.

\section{Materials and Methods}

\subsection{Silage Production}

This study consisted of three trials to investigate the effects of a dual-purpose inoculant on corn silage production from a laboratory environment to farm conditions. The forage harvest operation and inoculant dosage were similar in the three trials. Briefly, whole-plant corn was harvested at one-half to two-thirds milk line stage and chopped at $1-2 \mathrm{~cm}$ theoretical lengths. Chopped forages were divided into piles and randomly assigned to one of two treatments: treated with LAB(DPI) or without (control). DPI contained Lactobacillus plantarum (L. plantarum, LP1028) and Lactobacillus buchneri (L. buchneri, LBC1029) at application rates of $2.5 \times 10^{5} \mathrm{cfu}$ and $5.0 \times 10^{5} \mathrm{cfu}$ per gram of fresh forage, respectively.

The first trial was conducted between June and September 2017. Forages with $24.35 \%$ DM were filled into polyethylene vacuum bags $(35 \mathrm{~cm} \times 56 \mathrm{~cm})$. Later, a vacuum packing machine (YIZUO TY-760, Yizuo Co. Ltd., Taiwan) was used to pump out the air and seal the bag to prepare $0.5-\mathrm{kg}$ vacuum-packed minisilos. After $45 \mathrm{~d}$ and $105 \mathrm{~d}$ of storage, silos were opened for further analysis. Each treatment was performed in triplicate. The second trial was performed between April and July 2018. Forages with 39.89\% DM were chopped and ensiled in round bales $115 \mathrm{~cm}$ in diameter and $120 \mathrm{~cm}$ long by a stationary baler (Orkel MP 2000 Compactor, Orkel, Fannrem, Norway). After $60 \mathrm{~d}$ and $90 \mathrm{~d}$ of storage, silos were opened for further analysis. Each treatment was performed in triplicate. The third trial was conducted between February and July 2019. Forages with 32.68\% DM were filled and compacted in a 40-t bunker silo using the Dorset wedge method [26] and completed within two days. Forages in the right half of the bunker silo were treated with inoculant during the filling and compaction process, while the other half was not. After $45 \mathrm{~d}$ and $105 \mathrm{~d}$ of conservation, the bunker silo was opened for further analysis. The daily feed-out rate of the bunker silo was approximately $30 \mathrm{~cm}$ per day. 


\subsection{Chemical Composition}

Forage and silage samples were collected for chemical analysis. All samples were blinded and randomized by another investigator before testing. DM was determined by drying the samples in a forced-air oven at $60{ }^{\circ} \mathrm{C}$ for $48 \mathrm{~h}$. Subsamples were sent to the laboratory at the Livestock Research Institute (Heng-Chun, Taiwan) for analysis of CP, ADF, NDF, WSC, starch, and ammonia nitrogen. Silage extract was prepared by mixing $25 \mathrm{~g}$ samples with sterile reverse osmosis water at a ratio of 1:9 in a blender (Oster 6641 Cube 12-Speed Blender, Sunbeam Products, Inc., FL, US) for $1 \mathrm{~min}$. After homogenization, silage $\mathrm{pH}$ was measured using a pH meter (Suntex SP-701, Suntex Instruments Co., Ltd., Taipei, Taiwan). A 2-mL silage extract was centrifuged at $10,000 \times g$ for $5 \mathrm{~min}$, and the supernatant was filtered with a $0.22-\mu \mathrm{m}$ syringe filter for HPLC analysis to quantify the levels of lactic acid, volatile fatty acids, and propylene glycol in samples. HPLC (Hitachi L-7300, Hitachi, Tokyo, Japan) was coupled with a refractive index detector (Hitachi L-7490, Hitachi, Tokyo, Japan) and a UV detector (Hitachi L-7420, Hitachi, Tokyo, Japan). The column was Phenomenex Rezex ${ }^{\mathrm{TM}}$ ROA-Organic Acid H+ (8\%) $($ LC Column $300 \mathrm{~mm} \times 7.8 \mathrm{~mm})$ (Phenomenex, CA, USA) with a mobile phase of $0.005 \mathrm{~N}$ sulfuric acid at a flow rate of $0.6 \mathrm{~mL} / \mathrm{min}$ at $75^{\circ} \mathrm{C}$.

\subsection{Microbial Counts and Aerobic Stability}

The silage extract was diluted serially to determine LAB along with yeast and mold counts (YMC). LAB counts were measured using de Man, Rogosa, and Sharpe agar medium (MRS; Difco Laboratories, Detroit, MI, USA) modified with $10 \mathrm{ppm}$ sodium azide and $10 \mathrm{ppm}$ cycloheximide. YMC was measured with potato dextrose agar medium (PDA; Difco Laboratories, Detroit, MI, USA). MRS agar medium was incubated anaerobically at $37^{\circ} \mathrm{C}$ for $48 \mathrm{~h}$, and PDA agar medium was incubated aerobically at $25^{\circ} \mathrm{C}$ for $72 \mathrm{~h}$. After incubation, visible colonies were counted to calculate the number of cfu per gram of silage. All samples were blinded and randomized before testing by another investigator.

Aerobic stability was defined as the time required for raising the silage temperature $2{ }^{\circ} \mathrm{C}$ above the ambient temperature. This parameter was measured by placing $500 \mathrm{~g}$ of samples in an insulated polystyrene container with a perforated lid that allowed air to enter. Temperature sensors were inserted into the geocentric center of the samples, and data were recorded every $15 \mathrm{~min}$ by a data logger (TOHO TRM-20, Jetec Electronics Co., Ltd., Taichung, Taiwan) until heating was detected. All samples were blinded and randomized by another investigator before testing. The aerobic stability curve was plotted using the temperature data against aerobic exposure time, and the area under the curve, known as ASI, indicated the heat accumulated in silage over time. Recently, the infrared thermography technique has been recognized as a noninvasive way to evaluate silage deterioration at feed-out [20,27]. In this study, a FLIR T420 infrared camera (FLIR T420 Systems AB, FLIR Systems, Taby, Sweden) was used in the bunker silage trial to record the temperature of the exposed silo face, and the temperature data were used for ASI calculation to determine heat accumulation in different silage layers under different treatments.

\subsection{Statistical Analysis}

Experiments in this study had a completely randomized design with two treatments. Data were analyzed using Prism 8.0 (GraphPad Software, CA, USA) and SPSS 20.0 (IBM, New York, NY, USA). The effects of DPI on silage nutritive value were analyzed using an unpaired Student's $t$-test. For microbial data, a $\log$ (base ten) transformation was performed for normalization prior to the statistical analysis. Furthermore, a linear regression analysis was applied to aerobic exposure data, and an ANCOVA was used to compare the slopes and intercepts, to understand the changes in each parameter over time between treatments. To assess the interaction effects between treatment and silage layer, ASI data were subjected to a two-way ANOVA with the fixed factors of treatment group and silage layer, using the GLM univariate procedure of SPSS 20.0 (IBM, NY, USA). All data were presented as the 
mean \pm SEM. A statistically significant level was declared at $p<0.05$, and tendencies were declared as $p \geq 0.05$ but $<0.1$.

\section{Results}

\subsection{Laboratory-Scale Silage}

The microbial inoculant effects were first assessed with minisilos, where forages were ensiled using vacuum bags and opened after $45 \mathrm{~d}$ and $105 \mathrm{~d}$ of conservation. As indicated in Table 1, after $45 \mathrm{~d}$ of storage, DPI silage had higher levels of ADF (23.1 vs. 28.7, $p=0.006)$, $\mathrm{NDF}(42.1$ vs. $50.7, p=0.028)$, and propylene glycol (0.39 vs. $0.51, p=0.04)$, but was lower in starch content ( 34.69 vs. $25.55, p=0.025$ ) than the control. DM seemed to be higher in $105-\mathrm{d}$ DPI silage (23.9 vs. $24.9, p=0.092)$ but no significant difference was found in $45 \mathrm{~d}$ ensiled forage. CP tended to be higher in 45-d DPI silage (6.54 vs. $6.80, p=0.054)$ but no significant difference was observed after $105 \mathrm{~d}$ of storage. Compared to the control, the lactate-to-acetate ratio (LA-AA ratio) was significantly lower in DPI silage after $45 \mathrm{~d}$ of storage ( 2.19 vs. $1.92, p=0.014)$, whereas no significant difference was found in other parameters or in 105-d ensiled forages. Despite no significant difference in YMC being detected between treatments after either $45 \mathrm{~d}$ or $105 \mathrm{~d}$ of conservation, there was a trend showing decreased YMC (4.42 vs. $4.02, p=0.069)$ and ammonia nitrogen ( 2.54 vs. 2.30, $p=0.057)$ in $105 \mathrm{~d}$ DPI silage. Additionally, LAB seemed to be higher in $45 \mathrm{~d}$ DPI silage (6.1 vs. $6.7, p=0.088$ ) but no significant difference was detected after $105 \mathrm{~d}$ of conservation. The inoculant effects became significant under aerobic exposure conditions. When silages were exposed to air for a certain period of time, YMC was significantly greater in the 105-d ensiled control than in the DPI silage ( $1 \mathrm{~d}$ : 6.69 vs. $5.78 \log 10 \mathrm{cfu} / \mathrm{g}, p=0.029 ; 3 \mathrm{~d}: 8.35 \mathrm{vs}$. $7.04 \log 10 \mathrm{cfu} / \mathrm{g}, p=0.028$ ) (Figure 1a). Additionally, control silage showed a higher $\mathrm{pH}$ than DPI silage after four days of aerobic exposure (5.73 vs. $4.59, p=0.045)$ (Figure $1 b$ ).

Table 1. Effects of inoculant application ${ }^{1}$ on the quality and chemical composition of laboratory minisilos at different ensiling periods.

\begin{tabular}{|c|c|c|c|c|c|c|}
\hline \multirow{2}{*}{ Chemical Composition $^{2}$} & \multicolumn{3}{|c|}{$45 \mathrm{~d}$} & \multicolumn{3}{|c|}{$105 \mathrm{~d}$} \\
\hline & Control & DPI & $p$ Value & Control & DPI & $p$ Value \\
\hline $\mathrm{DM}(\%)$ & $29.9 \pm 3.2$ & $24.9 \pm 0.3$ & 0.102 & $23.9 \pm 0.3$ & $24.9 \pm 0.5$ & 0.092 \\
\hline $\mathrm{CP}(\%)$ & $6.54 \pm 0.10$ & $6.80 \pm 0.08$ & 0.054 & $8.19 \pm 0.16$ & $9.81 \pm 1.51$ & 0.17 \\
\hline $\operatorname{ADF}(\%)$ & $23.1 \pm 1.1^{b}$ & $28.7 \pm 0.6^{\mathrm{a}}$ & 0.006 & $25.9 \pm 1.1$ & $26.7 \pm 0.9$ & 0.31 \\
\hline $\operatorname{NDF}(\%)$ & $42.1 \pm 3.0^{b}$ & $50.7 \pm 1.2^{\mathrm{a}}$ & 0.028 & $45.7 \pm 1.1$ & $47.4 \pm 0.7$ & 0.11 \\
\hline WSC (\%) & $1.7 \pm 0.3$ & $1.6 \pm 0.2$ & 0.336 & $2.23 \pm 0.4$ & $3.8 \pm 1.4$ & 0.18 \\
\hline Starch $(\%)$ & $34.69 \pm 2.77^{\mathrm{a}}$ & $25.55 \pm 1.81^{b}$ & 0.025 & $28.59 \pm 1.49$ & $25.88 \pm 0.96$ & 0.10 \\
\hline Ammonia nitrogen ( $\%$ of $\mathrm{DM})$ & $3.08 \pm 1.00$ & $2.67 \pm 0.74$ & 0.381 & $2.54 \pm 0.08$ & $2.30 \pm 0.09$ & 0.057 \\
\hline $\mathrm{pH}$ & $3.71 \pm 0.02$ & $3.72 \pm 0.01$ & 0.388 & $3.72 \pm 0.02$ & $3.72 \pm 0.01$ & 0.37 \\
\hline Lactic acid (\% of DM) & $3.58 \pm 0.36$ & $3.33 \pm 0.43$ & 0.337 & $3.49 \pm 0.28$ & $3.56 \pm 0.41$ & 0.45 \\
\hline Acetic acid (\% of DM) & $1.63 \pm 0.15$ & $1.73 \pm 0.20$ & 0.358 & $1.79 \pm 0.25$ & $2.05 \pm 0.12$ & 0.19 \\
\hline LA-AA ratio & $2.19 \pm 0.06^{\mathrm{a}}$ & $1.92 \pm 0.06^{b}$ & 0.014 & $2.00 \pm 0.24$ & $1.73 \pm 0.13$ & 0.18 \\
\hline Propylene glycol (\% of DM) & $0.39 \pm 0.05^{b}$ & $0.51 \pm 0.02^{\mathrm{a}}$ & 0.04 & $0.58 \pm 0.08$ & $0.63 \pm 0.04$ & 0.31 \\
\hline Butyrate $(\%$ of DM) & ND & ND & & ND & ND & \\
\hline LAB $\left(\log _{10} \mathrm{cfu} / \mathrm{g}\right)$ & $6.1 \pm 0.2$ & $6.7 \pm 0.4$ & 0.088 & $6.4 \pm 0.6$ & $5.9 \pm 0.5$ & 0.26 \\
\hline YMC ( $\left.\log _{10} \mathrm{cfu} / \mathrm{g}\right)$ & $2.94 \pm 0.63$ & $2.91 \pm 0.13$ & 0.487 & $4.42 \pm 0.21$ & $4.02 \pm 0.03$ & 0.069 \\
\hline Aerobic stability $(\mathrm{h})^{3}$ & 30 & 51 & & 30 & 47 & \\
\hline
\end{tabular}

${ }^{a, b}$ Mean values in the same row with different superscripts differed significantly. Values were presented as mean \pm SEM. ND: not detected.

${ }^{1}$ Control $(n=3)=$ no inoculant added; DPI $(n=3)=2.5 \times 10^{5} \mathrm{cfu} / \mathrm{g}$ of Lactobacillus plantarum and $5.0 \times 10^{5} \mathrm{cfu} / \mathrm{g}$ of Lactobacillus buchneri.

${ }^{2}$ WSC: water soluble carbohydrates; LA-AA ratio: lactate-to-acetate ratio; LAB: lactic acid bacteria; YMC: yeast and mold counts. ${ }^{3}$ Due to the limitation of equipment, only one replicate was measured for aerobic stability in this trial. 

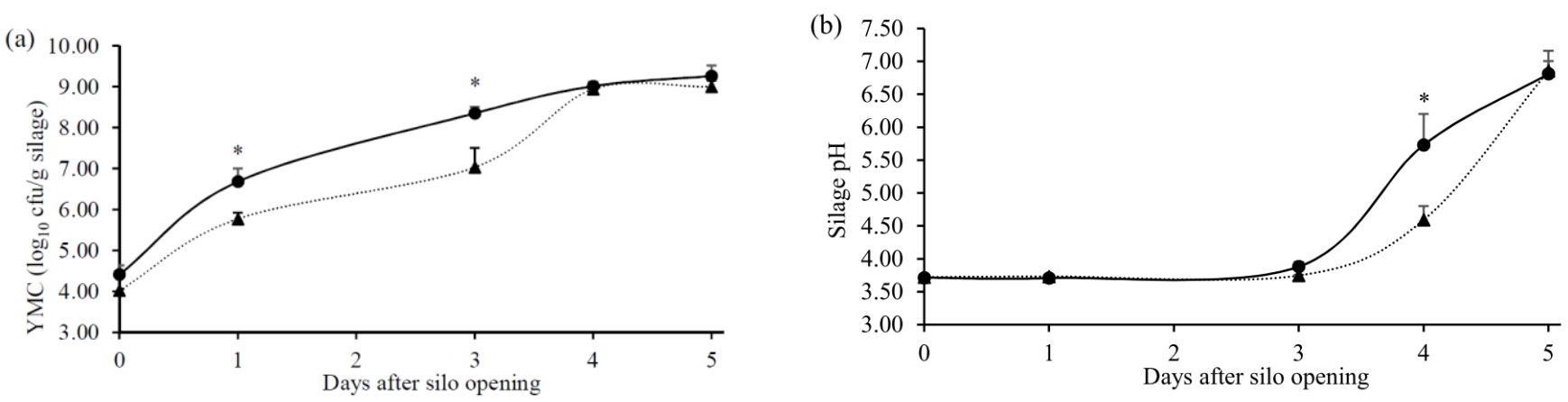

Figure 1. Changes in (a) yeast and mold counts (YMC) and (b) pH of 105-d ensiled laboratory-scale forages during aerobic exposure. Corn silage was treated without $(\bullet \bullet, n=3)$ or with $(* \cdots, n=3)$ DPI. Values with asterisk $\left({ }^{*}\right)$ within the same aerobic exposure time differed significantly $(p<0.05)$. Data were presented as mean $\pm \mathrm{SEM}$.

\subsection{Baled Silage}

In the second trial, silo bales were used to assess whether the microbial inoculant effects were consistent when moving from laboratory to farm. Silages were opened at $60 \mathrm{~d}$ and $90 \mathrm{~d}$ and analyzed for chemical composition, microbial counts, and aerobic stability. As shown in Table 2, DPI silage was richer in lactic acid content (2.58 vs. $2.91, p=0.039)$ after $60 \mathrm{~d}$ of conservation, but WSC tended to be lower (2.54 vs. $1.78, p=0.091)$ in 60 -d DPI silage. No significant difference was found between treatments in terms of other nutritive, chemical, and microbial parameters. In 90-d ensiled forages, the $\mathrm{pH}$ value of DPI silage was significantly higher than the $\mathrm{pH}$ value of the control (3.65 vs. 3.72, $p=0.004$ ), while lactate level (2.93 vs. $2.61, p=0.053)$ and LA-AA ratio $(2.02$ vs. $1.75, p=0.050)$ seemed to be lower in 90-d DPI silage. No significant difference was found in other parameters between treatments. When silages were exposed to air for a certain period of time, however, there was a numerical nonstatistical decrease in YMC in 90-d DPI silage (Figure 2).

Table 2. Effects of inoculant application ${ }^{1}$ on the quality and chemical composition of baled silage at different ensiling periods.

\begin{tabular}{|c|c|c|c|c|c|c|}
\hline \multirow{2}{*}{ Chemical Composition $^{2}$} & \multicolumn{3}{|c|}{$60 \mathrm{~d}$} & \multicolumn{3}{|c|}{$90 \mathrm{~d}$} \\
\hline & Control & DPI & $p$ Value & Control & DPI & $p$ Value \\
\hline DM (\%) & $41.2 \pm 1.2$ & $39.8 \pm 0.7$ & 0.179 & $41.6 \pm 1.3$ & $42.6 \pm 1.7$ & 0.34 \\
\hline $\mathrm{CP}(\%)$ & $9.3 \pm 0.2$ & $9.4 \pm 0.1$ & 0.229 & $9.1 \pm 0.2$ & $8.9 \pm 0.2$ & 0.27 \\
\hline $\operatorname{ADF}(\%)$ & $25.6 \pm 1.6$ & $25.5 \pm 1.4$ & 0.473 & $24.0 \pm 0.6$ & $23.3 \pm 0.6$ & 0.24 \\
\hline NDF (\%) & $45.6 \pm 1.0$ & $44.8 \pm 0.7$ & 0.284 & $41.8 \pm 1.2$ & $43.0 \pm 1.9$ & 0.31 \\
\hline WSC (\%) & $2.54 \pm 0.47$ & $1.78 \pm 0.06$ & 0.091 & $2.19 \pm 0.28$ & $2.56 \pm 0.55$ & 0.29 \\
\hline Starch $(\%)$ & $26.1 \pm 2.6$ & $26.8 \pm 2.4$ & 0.429 & $30.6 \pm 2.0$ & $31.7 \pm 1.8$ & 0.35 \\
\hline $\mathrm{pH}$ & $3.78 \pm 0.01$ & $3.83 \pm 0.06$ & 0.215 & $3.65 \pm 0.01^{b}$ & $3.72 \pm 0.01^{\mathrm{a}}$ & 0.004 \\
\hline $\begin{array}{l}\text { Lactic acid } \\
(\% \text { of DM) }\end{array}$ & $2.58 \pm 0.13^{b}$ & $2.91 \pm 0.06^{\mathrm{a}}$ & 0.039 & $2.93 \pm 0.06$ & $2.61 \pm 0.14$ & 0.053 \\
\hline $\begin{array}{l}\text { Acetic acid } \\
\text { (\% of DM) }\end{array}$ & $1.43 \pm 0.07$ & $1.40 \pm 0.10$ & 0.389 & $1.46 \pm 0.06$ & $1.50 \pm 0.14$ & 0.39 \\
\hline LA-AA ratio & $1.82 \pm 0.16$ & $2.10 \pm 0.11$ & 0.109 & $2.02 \pm 0.05$ & $1.75 \pm 0.12$ & 0.050 \\
\hline $\begin{array}{l}\text { Butyrate } \\
(\% \text { of DM) }\end{array}$ & ND & ND & & ND & ND & \\
\hline $\begin{array}{l}\text { Propylene glycol } \\
\text { (\% of DM) }\end{array}$ & $0.77 \pm 0.10$ & $0.61 \pm 0.07$ & 0.143 & $0.52 \pm 0.09$ & $0.69 \pm 0.10$ & 0.130 \\
\hline LAB $\left(\log _{10} \mathrm{cfu} / \mathrm{g}\right)$ & $6.82 \pm 0.27$ & $6.43 \pm 0.19$ & 0.150 & $5.00 \pm 0.00$ & $5.23 \pm 0.23$ & 0.19 \\
\hline YMC $\left(\log _{10} \mathrm{cfu} / \mathrm{g}\right)$ & $0.00 \pm 0.00$ & $0.62 \pm 0.62$ & 0.187 & $2.35 \pm 0.20$ & $1.42 \pm 0.71$ & 0.14 \\
\hline Aerobic stability (h) & $185 \pm 13$ & $165 \pm 40$ & 0.327 & $137 \pm 47$ & $136 \pm 57$ & 0.49 \\
\hline
\end{tabular}

${ }^{\mathrm{a}, \mathrm{b}}$ Mean values in the same row with different superscripts differed significantly. Values were presented as mean \pm SEM. ND: not detected.

${ }^{1}$ Control $(n=3)=$ no inoculant added; DPI $(n=3)=2.5 \times 10^{5} \mathrm{cfu} / \mathrm{g}$ of Lactobacillus plantarum and $5.0 \times 10^{5} \mathrm{cfu} / \mathrm{g}$ of Lactobacillus buchneri.

2 WSC: water soluble carbohydrates; LA-AA ratio: lactate-to-acetate ratio; LAB: lactic acid bacteria; YMC: yeast and mold counts. 


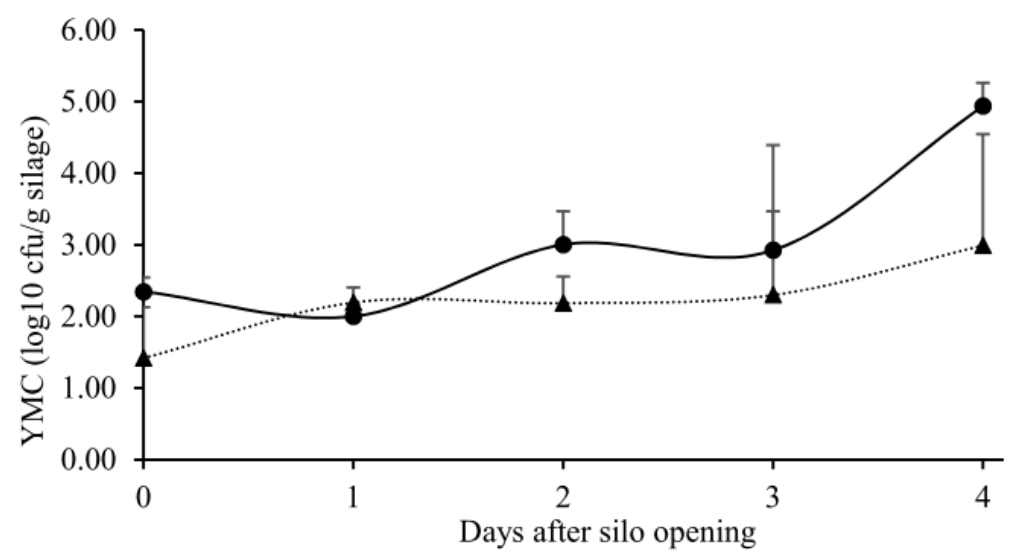

Figure 2. Changes in yeast and mold counts (YMC) of 90-d ensiled baled forages during aerobic exposure. Corn silage was treated without $(-\bullet, n=3)$ or with $(-\bullet, n=3)$ DPI. Data were presented as mean \pm SEM.

\subsection{Bunker Silage}

In the last trial, the silage scale was expanded from 400-kg silo bales to a $40-\mathrm{t}$ bunker silo. Among all the parameters, no significant difference was observed between treatments (Table 3). However, there was a trend toward increased acetic acid levels (3.79 vs. 4.73, $p=0.065)$ and decreased LA-AA ratio (0.40 vs. $0.30, p=0.087)$ in DPI silage after $45 \mathrm{~d}$ of conservation. In 105-d ensiled forages, the lactic acid level (3.28 vs. 2.90, $p=0.095$ ) seemed to be lower in DPI silage. Besides that, a tendency was observed to double the aerobic stability time in DPI silage (53 vs. $113 \mathrm{~h}, p=0.062$ ). Responses to inoculation were more remarkable at feed-out. To compare the change rate of $\mathrm{pH}$ value and lactic acid level between treatments, scatter plots were graphed using either of the two indicators against aerobic exposure time. The slopes of the linear regression lines from each treatment were compared, showing that both the $\mathrm{pH}$ value $(p=0.031)$ (Figure 3a) and lactic acid level $(p=0.002)$ (Figure $3 b)$ changed significantly rapidly in the control silage upon aerobic exposure. Compared with the control, yeast and mold growth tended to be slower in DPI silage (Figure 4). The daily temperature of the silo face was recorded with an infrared thermography camera to further understand the heat accumulation in silage under field conditions. The surface temperature image captured by an infrared thermography camera is demonstrated in Figure 5 as an example. Two-way ANOVA was performed to compare the main effects of the treatment and silage layer as well as their interaction effects on the ASI. The results indicated significant differences in ASI by both treatment and silage layer (Table 4), and the relationship between ASI and treatment was dependent upon the silage layer (treatment $\times$ layer interaction, $p<0.001$ ).
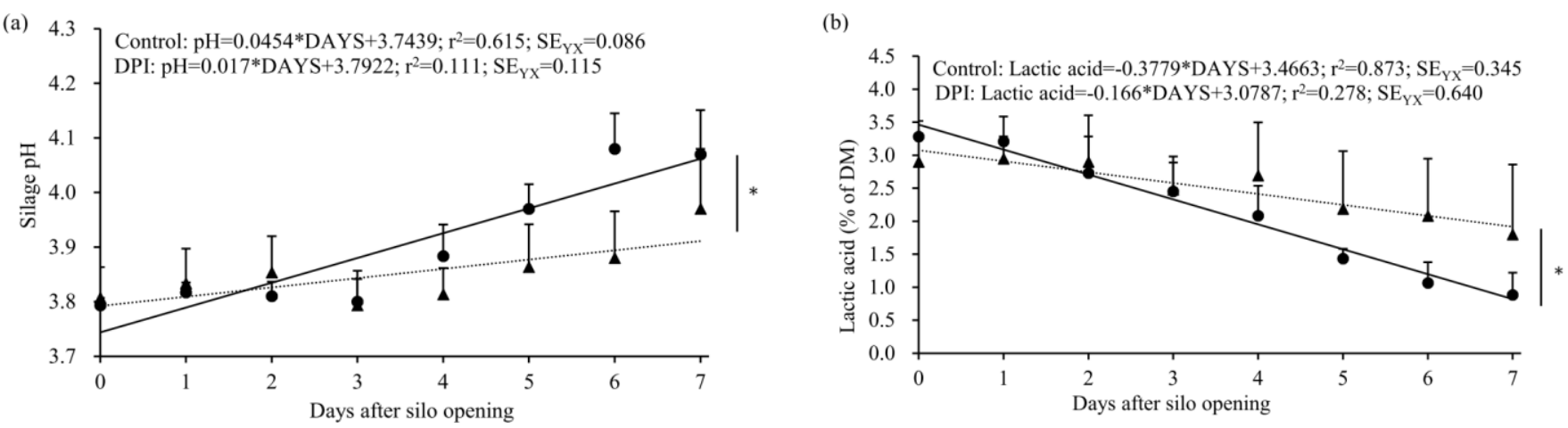

Figure 3. Changes in (a) $\mathrm{pH}$, and (b) lactic acid concentration of 105-d ensiled bunker forages during aerobic exposure. Corn silage was treated without $(-\bullet, n=3)$ or with $(* \cdots, n=3)$ DPI. Asterisk $\left.{ }^{*}\right)$ indicated that the slopes of linear regression lines differed significantly $(p<0.05)$. Data were presented as mean \pm SEM. SEYX: standard error of regression coefficient. 


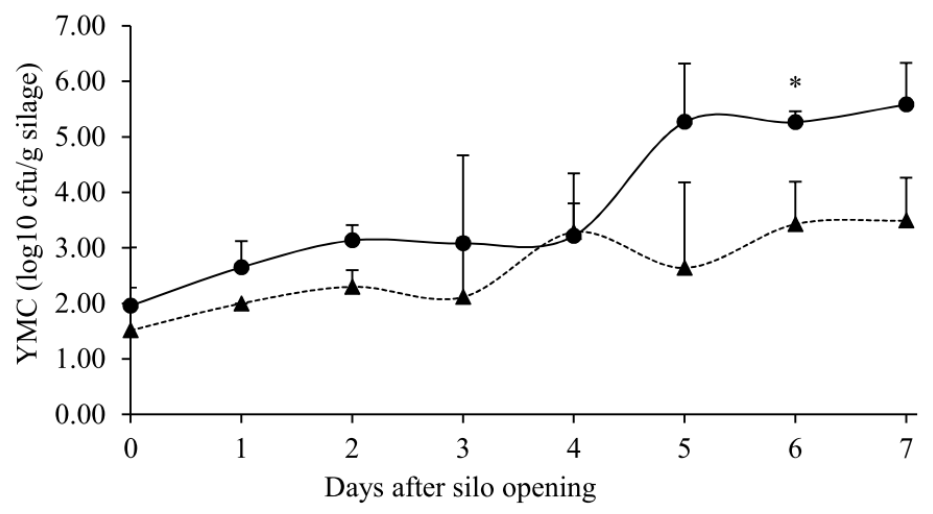

Figure 4. Changes in yeast and mold counts (YMC) of 105-d ensiled bunker forages during aerobic exposure. Corn silage was treated without $(-\bullet, n=3)$ or with $(\bullet \bullet, n=3)$ DPI. Values with asterisk $\left.{ }^{*}\right)$ within the same aerobic exposure time differed significantly $(p<0.05)$. Data were presented as mean \pm SEM.

Table 3. Effects of inoculant application ${ }^{1}$ on the quality and chemical composition of bunker silage at different ensiling periods.

\begin{tabular}{|c|c|c|c|c|c|c|}
\hline \multirow{2}{*}{ Chemical Composition $^{2}$} & \multicolumn{3}{|c|}{$45 d$} & \multicolumn{3}{|c|}{$105 \mathrm{~d}$} \\
\hline & Control & DPI & $p$ Value & Control & DPI & $p$ Value \\
\hline DM (\%) & $31.7 \pm 1.2$ & $31.7 \pm 0.8$ & 0.495 & $30.3 \pm 0.9$ & $30.4 \pm 0.5$ & 0.44 \\
\hline CP $(\%)$ & $7.83 \pm 0.20$ & $7.96 \pm 0.33$ & 0.378 & $7.59 \pm 0.03$ & $7.47 \pm 0.10$ & 0.16 \\
\hline $\operatorname{ADF}(\%)$ & $28.3 \pm 0.8$ & $28.9 \pm 0.5$ & 0.289 & $29.5 \pm 0.8$ & $30.7 \pm 0.8$ & 0.18 \\
\hline NDF $(\%)$ & $56.7 \pm 0.9$ & $58.0 \pm 0.4$ & 0.129 & $56.7 \pm 0.5$ & $58.8 \pm 1.4$ & 0.11 \\
\hline WSC (\%) & $1.86 \pm 0.24$ & $1.69 \pm 0.17$ & 0.301 & $1.02 \pm 0.40$ & $1.43 \pm 0.40$ & 0.26 \\
\hline Starch $(\%)$ & $20.7 \pm 0.9$ & $20.4 \pm 2.1$ & 0.450 & $19.3 \pm 0.7$ & $17.1 \pm 1.8$ & 0.15 \\
\hline $\mathrm{pH}$ & $3.76 \pm 0.04$ & $3.77 \pm 0.05$ & 0.423 & $3.79 \pm 0.01$ & $3.81 \pm 0.06$ & 0.42 \\
\hline $\begin{array}{l}\text { Lactic acid } \\
(\% \text { of DM) }\end{array}$ & $1.51 \pm 0.23$ & $1.41 \pm 0.17$ & 0.367 & $3.28 \pm 0.14$ & $2.90 \pm 0.20$ & 0.095 \\
\hline $\begin{array}{l}\text { Acetic acid } \\
\text { (\% of DM) }\end{array}$ & $3.79 \pm 0.34$ & $4.73 \pm 0.36$ & 0.065 & $3.43 \pm 0.10$ & $3.08 \pm 0.22$ & 0.11 \\
\hline LA-AA ratio & $0.40 \pm 0.05$ & $0.30 \pm 0.03$ & 0.087 & $0.96 \pm 0.02$ & $0.96 \pm 0.13$ & 0.50 \\
\hline $\begin{array}{l}\text { Butyrate } \\
\text { (\% of DM) }\end{array}$ & ND & ND & & ND & ND & \\
\hline $\begin{array}{l}\text { Propylene glycol } \\
\text { (\% of DM) }\end{array}$ & $1.80 \pm 0.64$ & $2.83 \pm 0.88$ & 0.199 & $2.07 \pm 0.05$ & $1.62 \pm 0.60$ & 0.249 \\
\hline LAB $\left(\log _{10} \mathrm{cfu} / \mathrm{g}\right)$ & $8.1 \pm 0.1$ & $8.2 \pm 0.1$ & 0.294 & $7.0 \pm 0.3$ & $7.6 \pm 0.3$ & 0.11 \\
\hline YMC ( $\left.\log _{10} \mathrm{cfu} / \mathrm{g}\right)$ & $3.8 \pm 1.8$ & $3.8 \pm 1.8$ & 0.493 & $2.0 \pm 1.1$ & $1.5 \pm 0.8$ & 0.37 \\
\hline Aerobic stability (h) & $53 \pm 13$ & $59 \pm 14$ & 0.389 & $53 \pm 11$ & $113 \pm 29$ & 0.062 \\
\hline
\end{tabular}

Values were presented as mean \pm SEM. ND: not detected. ${ }^{1}$ Control $(n=3)=$ no inoculant added; DPI $(n=3)=2.5 \times 10^{5} \mathrm{cfu} / \mathrm{g}$ of Lactobacillus plantarum and $5.0 \times 10^{5} \mathrm{cfu} / \mathrm{g}$ of Lactobacillus buchneri. ${ }^{2}$ WSC: water soluble carbohydrates; LA-AA ratio: lactate-to-acetate ratio; LAB: lactic acid bacteria; YMC: yeast and mold counts.

Table 4. Effects of inoculant application ${ }^{1}$ on heat accumulation in different layers of bunker silage during feed-out at field situation.

\begin{tabular}{|c|c|c|c|c|c|c|c|c|}
\hline \multirow{2}{*}{ Hours of Aerobic Exposure } & \multicolumn{2}{|c|}{ Control } & \multicolumn{2}{|c|}{ DPI } & \multirow{2}{*}{ SEM } & \multicolumn{3}{|c|}{$p$ Value } \\
\hline & Upper & Lower & Upper & Lower & & Treatment & Layer & Treatment $\times$ Layer \\
\hline $24 \mathrm{~h}$ & 693 & 678 & 691 & 680 & 0.065 & 0.003 & $<0.001$ & $<0.001$ \\
\hline $48 \mathrm{~h}$ & 1352 & 1332 & 1346 & 1332 & 0.115 & $<0.001$ & $<0.001$ & $<0.001$ \\
\hline $72 \mathrm{~h}$ & 2021 & 1998 & 2010 & 1997 & 0.199 & $<0.001$ & $<0.001$ & $<0.001$ \\
\hline $96 h$ & 2721 & 2684 & 2702 & 2684 & 0.311 & $<0.001$ & $<0.001$ & $<0.001$ \\
\hline
\end{tabular}

${ }^{1}$ Control $(n=7738)=$ no inoculant added; DPI $(n=7738)=2.5 \times 10^{5} \mathrm{cfu} / \mathrm{g}$ of Lactobacillus plantarum and $5.0 \times 10^{5} \mathrm{cfu} / \mathrm{g}$ of Lactobacillus buchneri. 


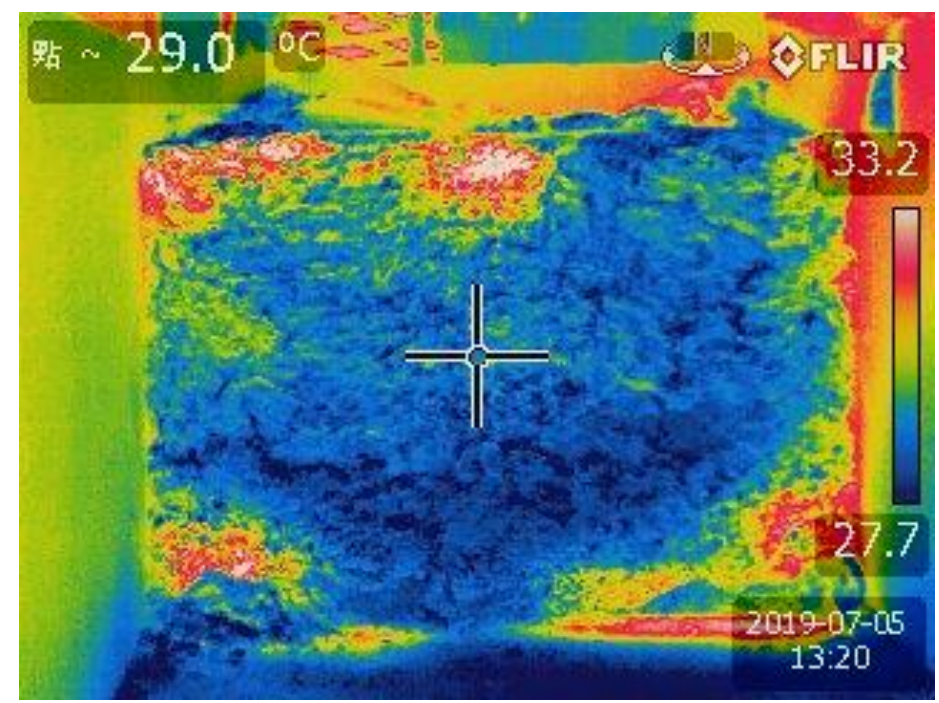

Figure 5. Thermogram of corn silage after 105-d storage. Corn silage was treated without (left-half) and with (right-half) DPI and the silo working face was exposed to air for $96 \mathrm{~h}$. Color indicated different temperature from low (blue, $27.7^{\circ} \mathrm{C}$ ) to high temperature (red, $33.2{ }^{\circ} \mathrm{C}$ ).

\section{Discussion}

This study evaluated the efficacy of DPI on the fermentation and aerobic stability of corn silage with different scales of silos. The inoculant consisted of two silage isolates, L. plantarum LP1028 and L. buchneri LBC1029, making it more adaptable to the field environment. DPI silage tended to have a lower LA-AA ratio, indicating more heterolactic fermentation, but no significant differences in nutrient composition was observed during the experiments. Heterolactic fermentation products, such as acetic acid, may inhibit spoilage microbial growth and therefore improve feed-out stability in silage.

All silages had $\mathrm{pH}$ values less than 4.00 , indicating adequate fermentation after conservation; however, the $\mathrm{pH}$ value seemed to be higher in DPI silage. This finding is common in previous studies, showing that L. buchneri-treated silages are often $0.1-0.2 \mathrm{pH}$ units higher than the untreated silages $[13,28,29]$. Regarding the acid profiles in our results, the LA-AA ratio tended to be lower in DPI silage. As the $\mathrm{pH}$ value is dependent on the silage acid profile, it is likely that the $\mathrm{pH}$ may rise when lactic acid (pKa of 3.86) is converted to acetic acid (pKa of 4.75) by L. buchneri [29,30].

Heterofermentation has been linked to DM losses in silage production [4]. Although DPI contains heterofermentative LAB, previous studies showed that using DPI did not affect the nutritive value in silage [21]. In agreement with the previous findings, our results demonstrated no significant difference in DM when silages were inoculated in all trials. In addition, the control and DPI silages did not differ from each other in terms of CP, ADF, $\mathrm{NDF}, \mathrm{WSC}$, starch, and ammonia nitrogen after prolonged storage in all trials. Reich and Kung [31] found that the unfavorable characteristics of L. buchneri may be overthrown in the presence of homolactic inoculant since each type of inoculant can target different aspects of fermentation [31].

L. buchneri is well known for its ability to produce acetic acid and propylene glycol, which inhibit yeast and mold growth [30]. Measurement of propylene glycol can be broadly used to determine whether inoculated L. buchneri dominates fermentation [29]. The ability of L. buchneri inoculant to increase the propylene glycol concentration in silage was not observed in this study except in $45 \mathrm{~d}$ laboratory minisilos $(p=0.04)$, probably because Lactobacillus diolivorans, a natural epiphytic bacterium on corn plants, can metabolize this compound to propionic acid and propanol [32]. Acetic acid is the second-highest acid in corn silage, the amount of which affects the aerobic stability of silage [29]. Based on the laboratory-silo results (Table 1), the LA-AA ratio was significantly lower at $45 \mathrm{~d}$ DPI $(p=0.014)$, and a nonsignificant decrease in the LA-AA ratio was also found at $105 \mathrm{~d}$ DPI. 
After silo opening, the lower pH (Figure 1b) and YMC (Figure 1a) in DPI further indicated that the onset of aerobic deterioration was delayed by inoculation. Similar results were observed in bunker silage, showing that the $\mathrm{pH}$ (Figure 3a) and lactic acid level (Figure 3b) changed more rapidly in the control under aerobic conditions, which may be attributed to lactate-assimilating microorganisms using lactic acid as an energy source and causing a $\mathrm{pH}$ increase when the silage is exposed to air [30].

Aerobic stability was not significantly different when this parameter was defined as the hours required for increasing the silage temperature to $2{ }^{\circ} \mathrm{C}$ above the ambient temperature; however, there was a tendency that applying DPI may double the aerobic stability time in the bunker silo after ensiling for 105 days. Queiroz et al. [21] proposed the idea of ASI, which considered heat accumulated in silage over time even if they started heating at a similar time [21]. With infrared camera technology, we were able to record the temperature of the silage working face on a daily basis for determining the ASI. Bunker silo results showed that applying DPI reduced heat accumulation in silage (Table 4), and the inoculant effects were dependent on the silage layer. Silage density is a function of height, and the density near the top of the silo is the lowest [33], indicating that top silage may be more susceptible to aerobic deterioration [5]. As a result, we can infer that DPI inoculation is likely to improve the aerobic stability in silages that are the most vulnerable to spoilage.

In the baled silage trial, responses to DPI inoculation were not obvious, which may be attributed to the high forage DM. Forage DM affects the density and porosity of silage [5]. The more porous the silage structure is, the more quickly it may spoil when exposed to air [29]. In high DM forage ( $>40-45 \%$ DM), low water availability limits LAB growth and slows fermentation [34]. A prolonged fermentation period means fewer antimicrobials to suppress the activity of yeasts and molds [29], which may explain why the inoculant effects were unremarkable in the silo bale trial, where the forage DM was approximately $40 \%$. Speaking of the on-farm losses over the ensiling process, management practices are far more important than inoculation. Inferior practices such as undesirable forage conditions, no coverings, and a slow feed-out rate may increase the DM losses by $41 \%$ during the feed-out phase [5]. Therefore, it can be said that the bacterial inoculant is an 'extra bonus' to reduce the risks from uncertain factors (e.g., weather), but only when the silages are well managed would the inoculants work.

In this study, the effectiveness of DPI was successfully demonstrated in both laboratory and field trials; however, the bunker size, which was smaller than the usual commercial size, might be the limitation of this research. On-farm management practices might be the main obstacle when conducting field trials in local farms. First, it is challenging to leave half of the forage untreated in a large silage bunker where compression and inoculation occurred simultaneously. If two silage bunkers were used, it was less likely to open two bunker silos at one time owing to on-farm management practices. Therefore, further studies are required to validate the results with larger commercial bunker silos to ensure that inoculant efficacy is maintained under such circumstances.

\section{Conclusions}

In this study, the effectiveness of DPI was first assessed with minisilos, and the laboratory results were later verified with commercial silos to understand its effects on the fermentation profile, nutritive value, aerobic stability, and heat accumulation during the feed-out phase in corn silage. The results showed that the application of DPI may slow the heat accumulation rate in silage and reduce the number of yeasts and molds under aerobic conditions without compromising the nutritive value of silage. These beneficial responses were attributed mostly to the tendency of the inoculant, which made the fermentation more heterolactic. Increasing acetic acid acted as an antifungal agent to suppress unfavorable microbial growth and thereby improve the aerobic stability of silage. As a result, we concluded that this DPI is an 'extra bonus' to reduce silage spoilage derived from uncertain factors (e.g., weather) at feed-out but only when good farm management is practiced. 
Author Contributions: Conceptualization, L.-C.K., S.-L.Y. and J.-S.L.; methodology, L.-C.K., S.-M.W. and C.-S.C.; validation, H.-M.W. and L.-C.K.; formal analysis, H.-M.W. and L.-C.K.; investigation, H.-M.W., L.-C.K., T.-Y.L. and H.-T.C.; resources, S.-M.W. and C.-S.C.; data curation, H.-M.W. and L.-C.K.; writing-original draft preparation, H.-M.W.; writing-review and editing, H.-M.W., S.-L.Y. and J.-S.L.; visualization, H.-M.W.; supervision, S.-L.Y. and J.-S.L.; project administration, L.-C.K., S.-L.Y. and J.-S.L.; funding acquisition, S.-L.Y. and J.-S.L. All authors have read and agreed to the published version of the manuscript.

Funding: This research received no external funding.

Institutional Review Board Statement: Not applicable.

Informed Consent Statement: Not applicable.

Data Availability Statement: The data presented in this study are available on request from the corresponding author. The data are not publicly available due to the policy of research projects.

Acknowledgments: This study was funded by SYNBIO TECH INC. (Kaohsiung, Taiwan). All study materials and laboratory equipment were provided by SYNBIO TECH INC. We also thank the staffs of SYNBIO TECH INC., Formosan sambar deer farm (Tainan, Taiwan), and goat farm (Changhua, Taiwan) for assistance throughout the study.

Conflicts of Interest: Hsiu-Ming Weng, Li-Chen Kao, Ting-Yu Lee, Hsiao-Tung Chang, San-Land Young, and Jin-Seng Lin are employed by SYNBIO TECH INC. Shu-Min Wang and Chia-Sheng Chen declare that there are no conflicts of interest.

\section{References}

1. Li, D.; Ni, K.; Zhang, Y.; Lin, Y.; Yang, F. Fermentation characteristics, chemical composition and microbial community of tropical forage silage under different temperatures. Asian Australas. J. Anim. 2019, 32, 665-674. [CrossRef] [PubMed]

2. Wang, Y.; Wang, C.; Zhou, W.; Yang, F.-Y.; Chen, X.-Y.; Zhang, Q. Effects of wilting and Lactobacillus plantarum addition on the fermentation quality and microbial community of Moringa oleifera leaf silage. Front. Microbiol. 2018, 9, 1817-1826. [CrossRef] [PubMed]

3. Dunière, L.; Sindou, J.; Chaucheyras-Durand, F.; Chevallier, I.; Thévenot-Sergentet, D. Silage processing and strategies to prevent persistence of undesirable microorganisms. Anim. Feed Sci. Technol. 2013, 182, 1-15. [CrossRef]

4. Wilkinson, J.M.; Davies, D.R. The aerobic stability of silage: Key findings and recent developments. Grass Forage Sci. 2013, 68, 1-19. [CrossRef]

5. Borreani, G.; Tabacco, E.; Schmidt, R.J.; Holmes, B.J.; Muck, R.E. Silage review: Factors affecting dry matter and quality losses in silages. J. Dairy Sci. 2018, 101, 3952-3979. [CrossRef]

6. Boudra, H.; Rouillé, B.; Lyan, B.; Morgavi, D.P. Presence of mycotoxins in sugar beet pulp silage collected in France. Anim. Feed Sci. Technol. 2015, 205, 131-135. [CrossRef]

7. Oladosu, Y.; Rafii, M.Y.; Abdullah, N.; Magaji, U.; Hussin, G.; Ramli, A.; Miah, G. Fermentation quality and additives: A case of rice straw silage. BioMed Res. Int. 2016, 2016, 7985167. [CrossRef]

8. Kung, L., Jr.; Stokes, M.R.; Lin, C. Silage additives. In Silage Science and Technology, 1st ed.; Buxton, D.R., Muck, R.E., Harrison, J.H., Eds.; Crop Science of America, Inc.: Madison, WI, USA, 2003; Volume 42, pp. 305-360.

9. Kandler, O. Carbohydrate metabolism in lactic acid bacteria. Anton. Leeuw. 1983, 49, 209-224. [CrossRef] [PubMed]

10. Filya, I.; Sucu, E.; Karabulut, A. The effects of Propionibacterium acidipropionici and Lactobacillus plantarum, applied at ensiling, on the fermentation and aerobic stability of low dry matter corn and sorghum silages. J. Ind. Microbiol. Biot. 2006, 33, 353-358. [CrossRef] [PubMed]

11. Bernardi, A.; Härter, C.J.; Silva, A.W.L.; Reis, R.A.; Rabelo, C.H.S. A meta-analysis examining lactic acid bacteria inoculants for maize silage: Effects on fermentation, aerobic stability, nutritive value and livestock production. Grass Forage Sci. 2019, 74, 596-612. [CrossRef]

12. Comino, L.; Tabacco, E.; Righi, F.; Revello-Chion, A.; Quarantelli, A.; Borreani, G. Effects of an inoculant containing a Lactobacillus buchneri that produces ferulate-esterase on fermentation products, aerobic stability, and fiber digestibility of maize silage harvested at different stages of maturity. Anim. Feed Sci. Technol. 2014, 198, 94-106. [CrossRef]

13. Blajman, J.E.; Paez, R.B.; Vinderola, C.G.; Lingua, M.S.; Signorini, M.L. A meta-analysis on the effectiveness of homofermentative and heterofermentative lactic acid bacteria for corn silage. J. Appl. Microbiol. 2018, 125, 1655-1669. [CrossRef] [PubMed]

14. Weinberg, Z.G.; Ashbell, G.; Hen, Y.; Azrieli, A.; Szakacs, G.; Filya, I. Ensiling whole-crop wheat and corn in large containers with Lactobacillus plantarum and Lactobacillus buchneri. J. Ind. Microbiol. Biot. 2002, 28, 7-11. [CrossRef] [PubMed]

15. Huisden, C.M.; Adesogan, A.T.; Kim, S.C.; Ososanya, T. Effect of applying molasses or inoculants containing homofermentative or heterofermentative bacteria at two rates on the fermentation and aerobic stability of corn silage. J. Dairy Sci. 2009, 92, 690-697. [CrossRef] [PubMed] 
16. Puntillo, M.; Gaggiotti, M.; Oteiza, J.M.; Binetti, A.; Massera, A.; Vinderola, G. Potential of Lactic Acid Bacteria Isolated From Different Forages as Silage Inoculants for Improving Fermentation Quality and Aerobic Stability. Front. Microbiol. 2020, $11,3091$. [CrossRef] [PubMed]

17. Ferrero, F.; Tabacco, E.; Piano, S.; Casale, M.; Borreani, G. Temperature during conservation in laboratory silos affects fermentation profile and aerobic stability of corn silage treated with Lactobacillus buchneri, Lactobacillus hilgardii, and their combination. J. Dairy Sci. 2021, 104, 1696-1713. [CrossRef] [PubMed]

18. Mari, L.J.; Schmidt, R.J.; Nussio, L.G.; Hallada, C.M.; Kung, L., Jr. Short communication: An evaluation of the effectiveness of Lactobacillus buchneri 40788 to alter fermentation and improve the aerobic stability of corn silage in farm silos. J. Dairy Sci. 2009, 92, 1174-1176. [CrossRef]

19. Borreani, G.; Tabacco, E. Temperature measurements of large scale silo face to assess aerobic deterioration of corn silage on farm. In Proceedings of the International Symposium on Forage Quality and Conservation, Sao Pedro, SP, Brazil, 28-30 November 2009; FEALQ: Piracicaba, SP, Brazil, 2009.

20. Borreani, G.; Tabacco, E. The relationship of silage temperature with the microbiological status of the face of corn silage bunkers. J. Dairy Sci. 2010, 93, 2620-2629. [CrossRef]

21. Queiroz, O.C.M.; Adesogan, A.T.; Arriola, K.G.; Queiroz, M.F.S. Effect of a dual-purpose inoculant on the quality and nutrient losses from corn silage produced in farm-scale silos. J. Dairy Sci. 2012, 95, 3354-3362. [CrossRef]

22. Gardner, N.J.; Savard, T.; Obermeier, P.; Caldwell, G.; Champagne, C.P. Selection and characterization of mixed starter cultures for lactic acid fermentation of carrot, cabbage, beet and onion vegetable mixtures. Int. J. Food Microbiol. 2001, 64, 261-275. [CrossRef]

23. Schnürer, J.; Magnusson, J. Antifungal lactic acid bacteria as biopreservatives. Trends Food Sci. Technol. 2005, 16, 70-78. [CrossRef]

24. Giraffa, G.; Chanishvili, N.; Widyastuti, Y. Importance of lactobacilli in food and feed biotechnology. Res. Microbiol. 2010, 161, 480-487. [CrossRef]

25. Muck, R.E.; Nadeau, E.M.G.; McAllister, T.A.; Contreras-Govea, F.E.; Santos, M.C.; Kung, L., Jr. Silage review: Recent advances and future uses of silage additives. J. Dairy Sci. 2018, 101, 3980-4000. [CrossRef] [PubMed]

26. Mickan, F.J.; Piltz, J.W. Silage Storage. In Successful Silage (TopFodder Silage Manual), 2nd ed.; Kaiser, A., Piltz, J.W., Burns, H., Griffths, N., Eds.; Dairy Australia and New South Wales Department of Primary Industry: New South Wales, Australia, 2003; pp. 217-252.

27. Junga, P.; Trávníček, P. Surface temperature of the exposed silo face as quick indicator of the decomposition process of maize silage. J. Cent. Eur. Agric. 2015, 16, 76-91. [CrossRef]

28. Kleinschmit, D.H.; Kung, L., Jr. A meta-analysis of the effects of Lactobacillus buchneri on the fermentation and aerobic stability of corn and grass and small-grain silages. J. Dairy Sci. 2006, 89, 4005-4013. [CrossRef]

29. Kung, L., Jr.; Shaver, R.D.; Grant, R.J.; Schmidt, R.J. Silage review: Interpretation of chemical, microbial, and organoleptic components of silages. J. Dairy Sci. 2018, 101, 4020-4033. [CrossRef] [PubMed]

30. Elferink, S.J.O.; Krooneman, J.; Gottschal, J.C.; Spoelstra, S.F.; Faber, F.; Driehuis, F. Anaerobic conversion of lactic acid to acetic acid and 1,2-propanediol by Lactobacillus buchneri. Appl. Environ. Microb. 2001, 67, 125-132. [CrossRef]

31. Reich, L.J.; Kung, L., Jr. Effects of combining Lactobacillus buchneri 40788 with various lactic acid bacteria on the fermentation and aerobic stability of corn silage. Anim. Feed Sci. Technol. 2010, 159, 105-109. [CrossRef]

32. Krooneman, J.; Faber, F.; Alderkamp, A.C.; Elferink, S.J.H.W.O.; Driehuis, F.; Cleenwerck, I.; Swings, J.; Gottschal, J.C.; Vancanneyt, M. Lactobacillus diolivorans sp. nov., a 1,2-propanediol-degrading bacterium isolated from aerobically stable maize silage. Int. J. Syst. Evol. Microbiol. 2002, 52, 639-646. [CrossRef]

33. D'Amours, L.; Savoie, P. Density profile of corn silage in bunker silos. Can. Biosyst. Eng. 2005, 47, 2-21. [CrossRef]

34. Whiter, A.G.; Kung, L., Jr. The effect of a dry or liquid application of Lactobacillus plantarum MTD1 on the fermentation of alfalfa silage. J. Dairy Sci. 2001, 84, 2195-2202. [CrossRef] 